\title{
A century of sea level data and the UK's 2013/14 storm surges: an assessment of extremes and clustering using the Newlyn tide gauge record
}

\author{
M. P. Wadey ${ }^{1}$, I. D. Haigh ${ }^{1,2}$, and J. M. Brown ${ }^{3}$ \\ ${ }^{1}$ Ocean and Earth Science, University of Southampton, National Oceanography Centre, Southampton, UK \\ ${ }^{2}$ School of Civil, Environmental and Mining Engineering and the UWA Oceans Institute, The University of Western \\ Australia, Perth, Australia \\ ${ }^{3}$ National Oceanography Centre, Liverpool, UK \\ Correspondence to: M. P. Wadey (m.p.wadey@ soton.ac.uk)
}

Received: 5 July 2014 - Published in Ocean Sci. Discuss.: 5 August 2014

Revised: 9 November 2014 - Accepted: 13 November 2014 - Published: 17 December 2014

\begin{abstract}
For the UK's longest and most complete sea level record (Newlyn), we assess extreme high waters and their temporal clustering; prompted by the 2013/2014 winter of storms and flooding. These are set into context against this almost 100-year record. We define annual periods for which storm activity and high sea levels can be compared on a yearby-year basis. Amongst the storms and high tides which affected Newlyn, the recent winter produced the largest recorded high water level (3 February 2014) and five other high water events above a 1 in 1 -year return period. The large magnitude of tide and mean sea level, and the close interevent spacings (of large return period high waters), suggests that the 2013/2014 extreme high water level "season" can be considered the most extreme on record. However, storm and sea level events may be classified in different ways. For example, in the context of sea level rise (which we calculate linearly as $1.81 \pm 0.1 \mathrm{~mm} \mathrm{yr}^{-1}$ from records between 1915 to 2014), a lower probability combination of surge and tide occurred on 29 January 1948, whilst the 1995/1996 storm surge season saw the most high waters of $\geq$ the 1 in 1 -year return period. We provide a basic categorisation of the four types of extreme high water level cluster, ranging from consecutive tidal cycles to multiple years. The assessment is extended to other UK sites (with shorter sea level records and different tide-surge characteristics), which suggests 2013/2014 was particularly unusual. Further work will assess clustering mechanisms and flood system "memory".
\end{abstract}

\section{Introduction}

Extreme sea levels and accompanying coastal floods are known globally for their devastating impacts, particularly in regions exposed to large storm surges which are densely populated and low-lying (e.g. Gönnert et al., 2001; Hanson et al., 2011). Coastal flood events cause extensive economic, cultural and environmental damage, and can also be associated with high mortality (e.g. Jonkman and Vrijling, 2008). In the last decade there have been several devastating events, including the two most costly natural disasters in US history: Hurricane Katrina which destroyed large swathes of New Orleans and other parts of the Gulf Coast in late Augustearly September 2005 with coastal floods killing more than 800 people (RMS, 2005; Jonkman et al., 2009); and Hurricane Sandy which hit the New Jersey shoreline on 29 October 2012, killing more than 100 people, generating the worst flooding in New York since records began in the 1920s, and causing an estimated USD 50 billion damage (Neria and Shultz, 2012). In November 2013, Typhoon Haiyan, the most intense storm to ever make landfall, impacted the islands of the central Philippines. This event left nearly 8000 people dead, missing or injured, and damaged or destroyed over 1.1 million houses (LeComte, 2014), much of the impact due to the effects of the storm surge. Over the coming century, extreme sea level events like these are expected to increase in magnitude, frequency and impact due to: increases in mean sea level (Haigh et al., 2010a; Wahl et al., 2011); possible changes in storminess (Church et al., 2013); and continued 
growth in populations and development at the coast (Hallegatte et al., 2013).

Northern Europe has a long history of extreme sea levels and coastal floods (e.g. Lamb, 1991). The greatest casualties have occurred along the North Sea coastlines; the Netherlands, UK, Belgium, German Bight and Denmark have repeatedly suffered human and agricultural losses (e.g. Gönnert et al., 2001; Plüß et al., 2001; De Kraker, 2006). In the UK, records suggest that tens to hundreds of thousands of people were drowned from events in 1099, 1421 and 1446 (Gönnert et al., 2001). Major UK coastal flood events, which included loss of human life, impacted the west coast in 1607 (Horsburgh and Horritt, 2006; RMS, 2007), the west and south coast in 1703 (RMS, 2003) and the south (DorsetDevon) coasts in 1824 (Lewis, 1979; Le Pard, 1999; West, 2010). In the past century notable events include the notorious North Sea floods of 1953, which killed 307 people in the UK, 1836 in the Netherlands and 17 in Belgium (Steers, 1953; McRobie et al., 2005; Gerritsen, 2005; Baxter, 2005); and the 1962 Elbe floods, which killed more than 300 people in Germany (Bütow, 1963). A more recent large event was Storm Xynthia, which struck the French Atlantic coast on the 28 February 2010, causing widespread coastal flooding and killing between 40 (Lumbroso and Vinet, 2011) and 65 people (Kolen et al., 2010).

In northern Europe and the UK in particular, the considerable problems associated with coastal flooding again came to the forefront during the most recent winter of 2013/2014, which saw a series of severe storms, waves, extreme sea levels and coastal floods (MetOffice, 2014; BBC, 2014a). On the 27-28 October 2013 a violent windstorm generated coastal flooding during a neap tide at Yarmouth on the Isle of Wight. This was followed by extreme high waters in the central English Channel during early November, and most notably the Xaver storm and accompanying storm surge (in both the Irish Sea and North Sea) on the 5-6 December 2013. The latter event was feared to be a repeat of 1953, and resulted in the flooding of more than 2500 properties (Environment Agency, 2014) and caused extensive coastal erosion and ecological damage. A series of coastal storms in January and February damaged defences and property on the southern UK coast (SCOPAC, 2014), and other regions, notably the remarkable destruction of the historical promenade in Aberystwyth in Wales and the collapse of the Dawlish railway line (the main train connection between Cornwall and the rest of England). High tides and storms continued into March with flooding and damage in the Channel Islands (BBC, 2014b).

What appears especially noteworthy about this most recent winter period is the large number of coastal flooding events occurring one after another over a relatively short period of time. Extreme sea level events are rarely assessed in terms of such sequencing or "clustering", although this is becoming an active research area due to a growing understanding of the mechanisms (e.g. non-independence of successive storm tracks) and the recovery time of flood system components (e.g. defences, communities), while being driven by a need for better estimates of insured losses (Mailier et al., 2006; Scotto et al., 2009; Vitolo et al., 2009; Villarini et al., 2013).

Therefore the aim of this paper is to assess how unusual this winter period of coastal flooding has been in the UK, compared with winters over the last century, both in terms of the number of large events and their clustering over a short time period. To do this we undertake, as a first step, a simple but detailed analysis of the UK's longest tide gauge record located at Newlyn in southwest England (Fig. 1), which, as of this year, covers the near continuous 100-year period from April 1915 to June 2014. A key goal in undertaking this study is to highlight the importance of the topic and promote discussion and further analysis.

We recognise Newlyn captures sea level extremes at only one location around the UK, at which events are not as extreme as those, for example, in the North Sea. However, Newlyn's record is of sufficient quality and length to demonstrate methods to identify and classify temporal clusters (e.g. underlying mean sea level trends and interannual tidal modulations and multi-decadal variations in storm surge activity across a centennial scale can be included in assessment of the results). We provide a brief summary of the 2013/14 winter storms in context with the (shorter) records at other tide gauges around the UK.

The specific study objectives are to:

1. Examine individual high waters at Newlyn that reach or exceed a 1 in 1-year annual probability. We use return periods from a national database commissioned by the Environment Agency (EA) that has been developed for coastal engineering and flood risk assessment (McMillan et al., 2011). We provide a summary of these large events, examining the astronomical tides, storm surge and mean sea level components that combined to cause elevated sea levels (Pugh, 2004). In particular, we investigate the influence of mean sea level rise, and then remove this to analyse the events in a more stationary framework.

2. Examine the events, from a clustering perspective, using the predefined threshold described above. We assess events from all 99 storm surge seasons in the Newlyn data set; and evaluate the most recent season to determine if this period is an outlier, in terms of the number of large events. We also briefly explore possible mechanisms driving different types of clustering.

The structure of the paper is as follows: a description of the data and methods is provided in Sect. 2; Sect. 3 describes the results from objectives 1 and 2. In Sect. 4 we discuss the types and causes of sea level clustering, outline directions for further work and give key conclusions of the study. 

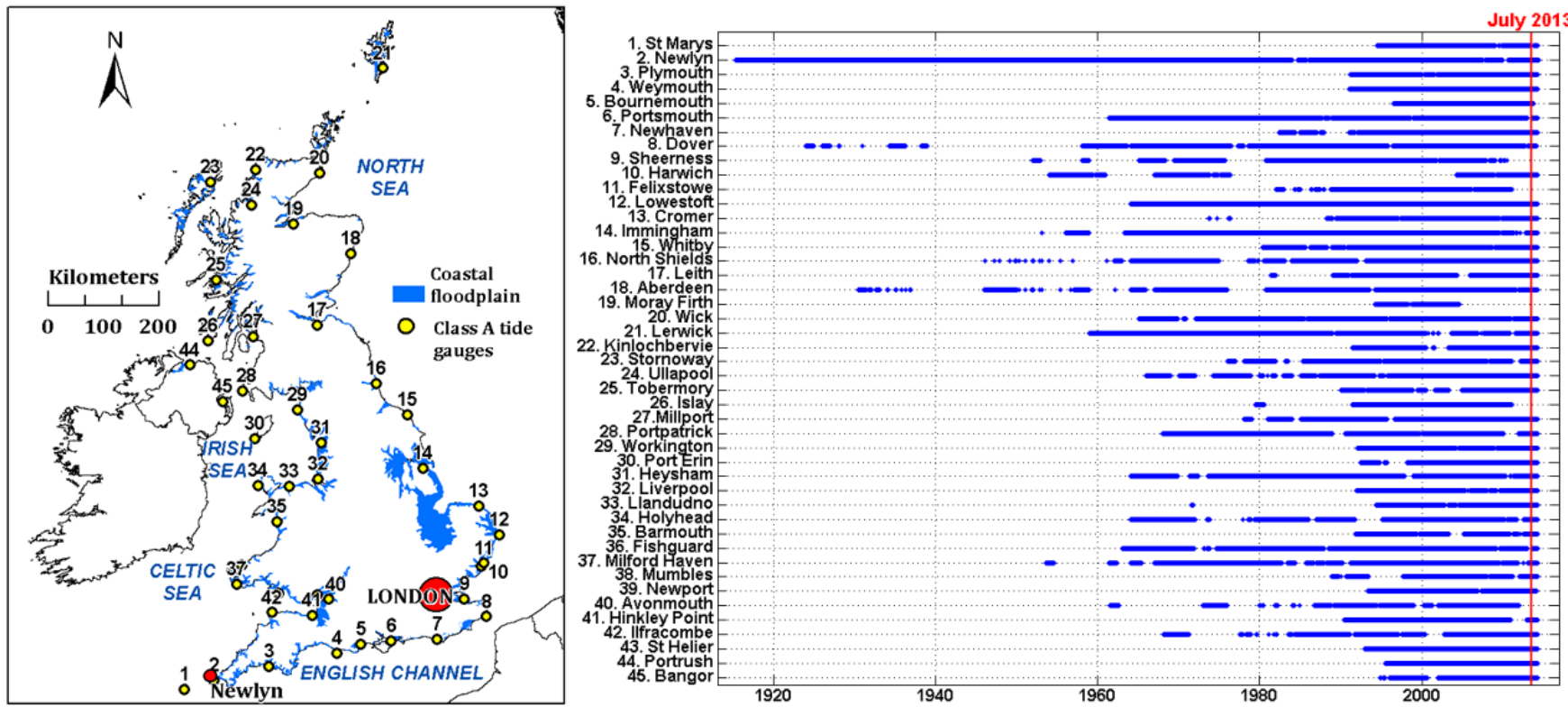

Figure 1. (a) Location map of Newlyn also showing the main seas around the UK and land broadly classified as at risk from coastal flooding (below $5 \mathrm{~m}$ Ordnance Datum Newlyn); (b) data coverage at the tide gauge locations including for the 2013/14 assessment.

\section{Data and methods}

Newlyn, in southwest England (Fig. 1a), has the longest continuous sea level record in the UK (Fig. 1b) and has been maintained as the principal tide gauge since 1915. For long periods of time it has had a dedicated gauge attendant, making it one of the highest quality long sea level records in the world (Araújo and Pugh, 2008). Newlyn is within the UK's "Class A" network of tide gauges, which includes 44 sites around the UK, 41 of which are currently active. The network is managed by the National Tide and Sea Level Facility (NTSLF), owned and funded by the Environment Agency (EA), and data is quality controlled and archived by the British Oceanographic Data Centre (BODC). The 15 min data values are available for January 1993 onwards and hourly values prior to 1993 (Fig. 2). The sampling frequency of these time series were not changed (i.e. interpolated) for this analysis (so any levels quoted may be directly obtained from the raw data). These sampling rates filter out high frequency seiches, swell and wind waves. UK tide gauges have been systematically levelled and checked. The BODC's archived data is accompanied by flags which identify problematic data (e.g. mechanical or software problems, old chart records). In addition we have also undertaken secondary checks of the data, with spurious data flagged and then removed. All sea levels are relative to chart datum (CD) at Newlyn.

We separated the observed sea level record at Newlyn into its main component parts (Pugh, 2004): mean sea level (MSL); astronomical tide; and non-tidal residual (Fig. 2). To isolate the contribution of sea level changes caused by in- dividual storm events (rather than longer term seasonal or inter-annual changes in meteorology), the MSL component (indicative of seasonal, inter-annual and longer-term change) was derived using a 30 day running mean of the observed sea level time series (Fig. 2a). The tidal component was estimated using the T-Tide harmonic analysis software (Pawlowicz et al., 2002) (Fig. 2b). Analyses were undertaken for each calendar year with the standard set of 67 tidal constituents. The non-tidal residual was calculated by subtracting the MSL and tidal component from the total measured sea level (Fig. 2c).

The non-tidal residual primarily contains the storm surge component, which represents sea level forcing due to changes in atmospheric pressure and wind (Gill, 1982). However, surges are not freely propagating Kelvin waves, but respond strongly to the presence or absence of incidental meteorological forcing, as well as locally determined surge development and decay, and interact with the tide (Proudman, 1955, 1957; Doodson, 1956; Rossiter, 1961; Prandle and Wolf, 1978). Hence, rather than directly using the non-tidal residual, we calculated the difference between the elevation of every observed twice-daily (i.e. semi-diurnal) high water value and the corresponding high water value of the predicted peak, to generate time series of "skew surge" (Fig. 2c). Skew surge is a more relevant parameter (than the non-tidal residual) in the assessment of extreme sea level events (de Vries et al., 1995; Horsburgh and Wilson, 2007).

We then estimated the return period of each twice-daily measured high water level value at Newlyn using information extracted from the latest EA national extreme value statistics (McMillan et al., 2011; Batstone et al., 2013). The EA 

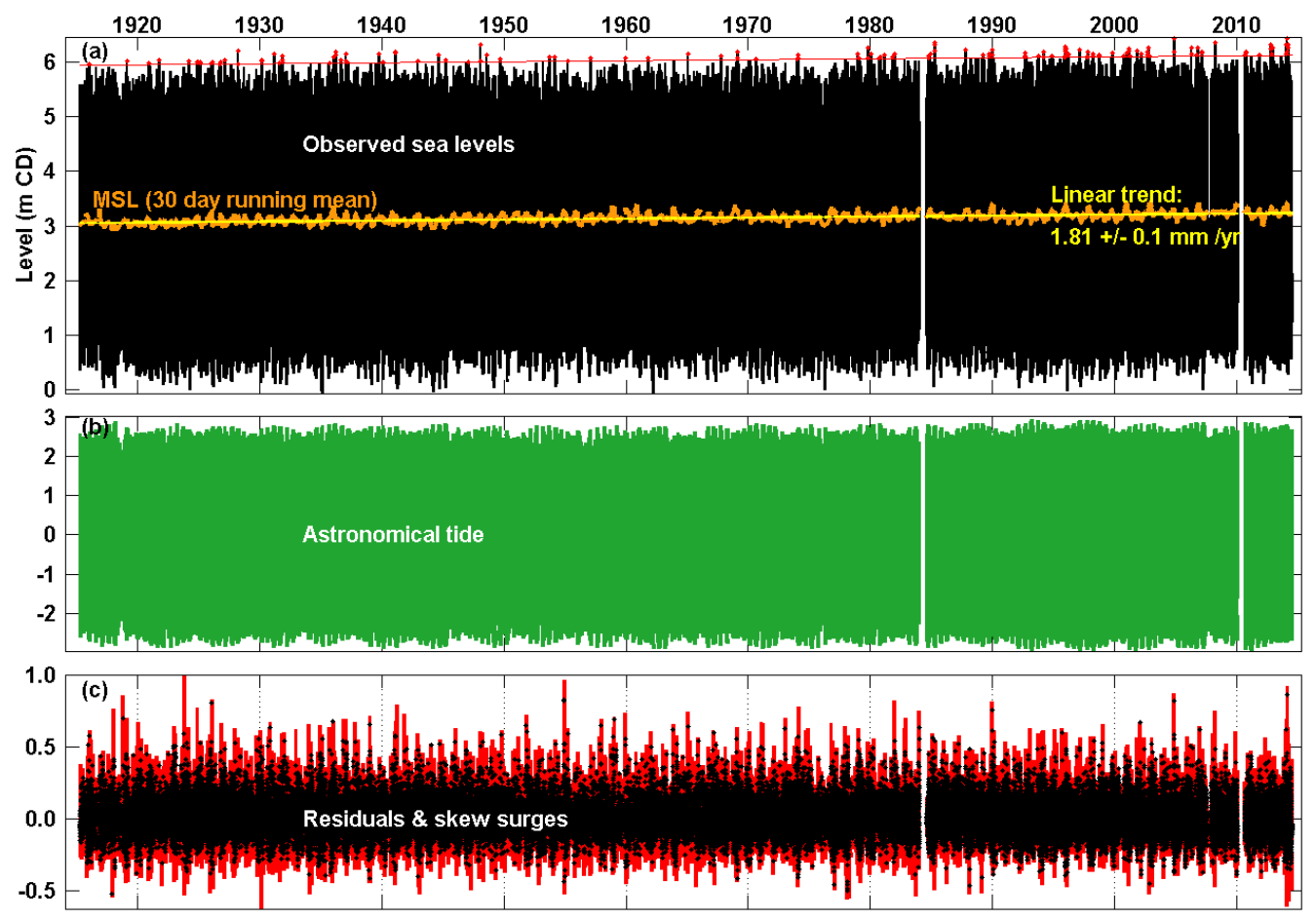

Figure 2. (a) Observed sea levels (with the 30 day running mean and the linear trend displayed), and shown in red the 1 in 1-year threshold offset for linear SLR; (b) astronomical tide; (c) non-tidal residuals (red line) and skew surges (black dots).

return periods are relative to a baseline MSL, which corresponds to MSL for the year 2008. Hence, in order to directly compare the return levels throughout the record, we offset the stored high water levels using a simple linear MSL offset method (Haigh et al., 2010b). Fitting a trend, using linear regression to a time series of annual MSL values, indicates a rate of MSL rise at Newlyn of $1.81 \pm 0.1 \mathrm{~mm} \mathrm{yr}^{-1}$ for the period from April 1915 to June 2014. This compares well with the previous estimate of $1.77 \pm 0.12 \mathrm{~mm} \mathrm{yr}^{-1}$ calculated by Araújo and Pugh (2008) at Newlyn for the period 19152005. The time series of twice-daily measured high water levels were then offset by this MSL rate (i.e. the values before 2008 were increased by an amount relative to the number of years before 2008, and the values after 2008 were decreased by an amount relative to the number of years after 2008). A second set of return period values were estimated for each of the offset twice-daily measured high water levels, again using the EA statistics. We stored the offset high water values that equalled or exceed the 1 in 1-year return period threshold at Newlyn $(6.11 \mathrm{mCD}$; Table 1b). For each of these values, we also stored the height of the MSL and predicted tide at that exact time and the corresponding skew surge level.

Newlyn is macro tidal, with a smaller tidal range than most of the English west coast, but larger than most sites along the south coast. The spring tidal range (Table 1a) is more than double the range of neap tides, and further increases substantially during periods of tides heightened by inter-annual pre-
Table 1a. Tidal range at Newlyn. Astronomical tidal levels are those computed for the period 2008 to 2026, available from the National Tide and Sea Level Facility (www.ntslf.org).

\begin{tabular}{ll}
\hline Description & $\begin{array}{l}\text { Tidal range } \\
(\mathrm{m})\end{array}$ \\
\hline $\begin{array}{l}\text { Highest and lowest astronomi- } \\
\text { cal tide (HAT and LAT) }\end{array}$ & 6.22 \\
Mean spring tidal range (MSR) & 4.75 \\
Mean neap tidal range (MNR) & 2.31 \\
\hline
\end{tabular}

Table 1b. Sea levels at Newlyn (to base year of 2008).

\begin{tabular}{ll}
\hline Description & $\begin{array}{l}\text { Elevation } \\
(\mathrm{mCD})\end{array}$ \\
\hline Mean high water neaps (MHWN) & 4.35 \\
Mean high water springs (MHWS) & 5.54 \\
Highest astronomical tide (HAT) & 6.13 \\
1 in 1 year & 6.11 \\
1 in 10 years & 6.32 \\
1 in 100 years & 6.51 \\
1 in 1000 years & 6.68 \\
\hline
\end{tabular}

cessions associated with the orbit of the Moon, namely: the 4.4-year cycle of lunar perigee and the 18.6-year lunar nodal tidal cycle (Haigh et al., 2011). The highest astronomical tide 
Table 1c. Extreme storm surges and high tide at Newlyn (CD refers to "chart datum"; $0 \mathrm{mCD}$ is approximately the lowest astronomical tide level at each port).

\begin{tabular}{lll}
\hline Description & Date & Level (m) \\
Largest NTR & $28 / 10 / 1923,16: 00$ UTC & 1.04 (peak of SL event: 5.86 mCD) \\
Largest skew surge & $14 / 02 / 2014,16: 45$ UTC & 0.86 (peak of SL event: 6.08 mCD) \\
\hline
\end{tabular}

(HAT) is in fact higher than the 1 in 1-year sea level return period at Newlyn $(6.13 \mathrm{mCD}$ compared with $6.11 \mathrm{mCD}$; Table 1b). Compared with sites on the UK east and west coast, surges at Newlyn are relatively small. The average skew surges associated with the 1 in 1-year and 1 in 10-year high water level are 0.24 and $0.51 \mathrm{~m}$ respectively. The largest skew surge event of $0.86 \mathrm{~m}$ occurred on the 14 February 2014 (Table 1c), with five incidences exceeding $0.8 \mathrm{~m}$ in the record, although these extreme surges have so far not often combined with the most extreme tides. As illustrated in Fig. 2c, the largest non-tidal residuals are often larger than the corresponding skew surge values. This is partly due to non-linear tide-surge interaction (Horsburgh and Wilson, 2007) and also due to the simple fact that the peak of the storm surge does not always coincide with high water.

\section{Results}

\subsection{Extreme high sea levels}

From 15 April 1915 to 30 June 2014, there have been 84 occasions when high water has equalled or exceeded the 1 in 1-year return period level (relative to the 2008 baseline) at Newlyn. The dates of these events are shown in Fig. 3 in red (with the $y$ axis plotted on both a normal - Fig. $3 \mathrm{a}-$ and $\log$ scale - Fig. 3b). The increase in MSL at Newlyn has meant, as expected, that there are more occurrences of high water reaching or exceeding the threshold in recent years, in agreement with the findings of Haigh et al. (2010a, 2011) for the English Channel. There have been 15 occurrences of $a \geq 1$ in 5-year return period, five occurrences of a $\geq 1$ in 10-year return period and only two occurrences of $a \geq 1$ in 25-year return period (in 2004 and 2014). When the high water time series is linearly offset for MSL changes (shown by the blue bars in Fig. 3a and b) there are 147 occasions when high water has equalled or exceeded the 1 in 1-year return period at Newlyn. After offsetting, there have been 25 occurrences of a high water $\geq$ the 1 in 5 -year return period, seven occurrences of $\mathrm{a} \geq$ the 1 in 10-year return period and only four occurrences of $\mathrm{a} \geq$ the 1 in 25 -year return period $(1948,1985$, 2004 and 2014).

The top 20 largest high water levels, ordered by total sea level, are listed in Table 2. The recent 2013/2014 storm surge season generated the largest sea level on record at Newlyn. This occurred on the 3 February 2014 and resulted from a large tidal high water of $2.61 \mathrm{mCD}$ plus a $0.45 \mathrm{~m}$ skew surge, superimposed on a MSL of $3.37 \mathrm{mCD}$. This event caused coastal flooding and damage in Cornwall and Devon (BBC, 2014c); and was one of a series of large sea level (and swell wave) events that occurred at the start of 2014 (Table 3). MSL was approximately $12 \mathrm{~cm}$ lower in 1948 than in 2014. This means that the fifth largest sea level on record, which occurred on the 29 January 1948, when offset by MSL change, is actually the most extreme from a return period perspective (with a return period of 37 years; Fig. 3 and Table 2). Within the top 20 water levels, the 2013/2014 winter season also generated the 7th, 9th and 12th largest water levels, which occurred on the 3 January 2014, and the 2 and 3 March 2014, respectively. On the 3 January 2014, the tidal high water level was $2.77 \mathrm{mCD}$ and the skew surge was only $0.18 \mathrm{~m}$. The second largest sea level in the overall record (27 October 2004), which is also associated with coastal flooding across Cornwall (Easterling, 2004), had a much larger skew surge $(0.82 \mathrm{~m})$ than the event on the 3 February 2014, but occurred on a smaller high tide $(2.31 \mathrm{mCD})$. Clearly, as highlighted by Quinn et al. (2014) (in an assessment of UK coastal sea level time series) there is substantial variability between each high water event at Newlyn, because different combinations of tide and surge, superimposed on different MSLs, combine to give the total observed sea levels.

\subsection{Extreme sea level clustering}

Having assessed individual high waters $\geq$ the 1 in 1-year return period, we now examine the temporal clustering of high waters across the Newlyn record by considering them in the context of seasons. Rather than dividing seasons by calendar year, we separate by the dates of the typical storm surge season for continuity. The months in which all $147 \geq 1$ in 1-year (offset) high waters occurred is shown in Fig. 4a. The typical seasonal period through which high waters $\geq 1$ in 1 year occur at Newlyn is from September to March of the following year, although several extreme sea levels have occurred in August and as late as April. The earliest extreme high water within any of these storm surge seasons occurred on the 7 August 1948 (and had a 1 in 4-year return period); whereas the latest extreme high water occurred on the 14 April 1945 (and had a 1 in 2-year return period). March and October are the months associated with the largest number of extreme high waters. This is partly because astronomical tides are typically largest around the time of the equinoxes, when the declination of the Sun is zero (i.e. over the equator) (Pugh, 2004). From May to July, storms (and tides) are less extreme. 

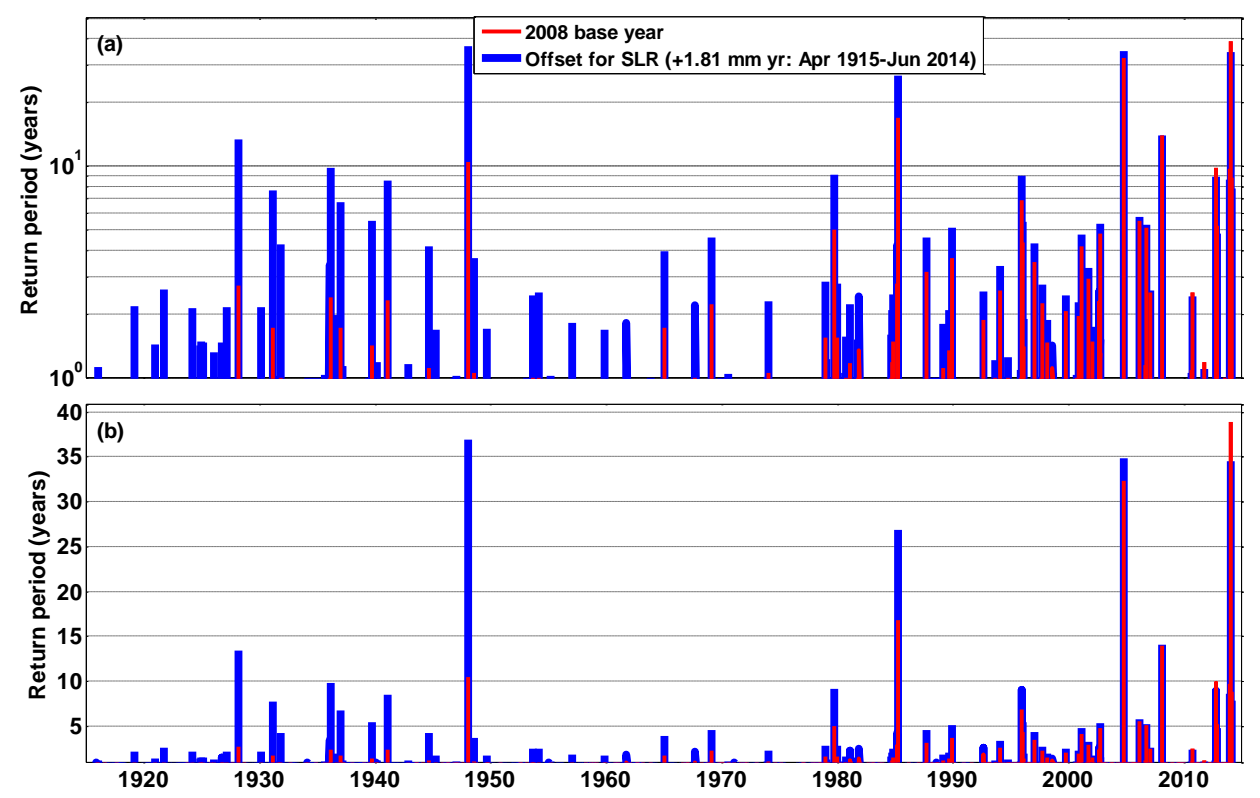

Figure 3. (a) Return periods at Newlyn for high water events of $\geq 1$ in 1 year, for both the fixed 2008 baseline and offset for SLR across the data record; (b) plotted with a non-logarithmic $y$ axis scale.

Table 2. The largest sea level events at Newlyn: top 20 (ranked by sea level).

\begin{tabular}{rrlrrrrr}
\hline $\begin{array}{r}\text { Sea level } \\
\text { rank }\end{array}$ & $\begin{array}{r}\text { Return period } \\
\text { rank }\end{array}$ & $\begin{array}{l}\text { Date and time } \\
\text { (UTC) }\end{array}$ & $\begin{array}{r}\text { Observed SL } \\
(\mathrm{mCD})\end{array}$ & $\begin{array}{r}\text { Tide } \\
(\mathrm{mCD})\end{array}$ & $\begin{array}{r}\text { Skew surge } \\
(\mathrm{m})\end{array}$ & $\begin{array}{r}\text { MSL } \\
\text { Return period } \\
(2008)\end{array}$ & $\begin{array}{r}\text { Return period } \\
(\text { offset })\end{array}$ \\
\hline 1 & 3 & $03 / 02 / 2014,07: 00$ & 6.44 & 2.61 & 0.45 & 3.37 & 39 \\
2 & 2 & $27 / 10 / 2004,16: 15$ & 6.42 & 2.31 & 0.82 & 3.29 & 32 \\
3 & 4 & $07 / 04 / 1985,06: 00$ & 6.36 & 2.78 & 0.42 & 3.16 & 17 \\
4 & 6 & $10 / 03 / 2008,06: 15$ & 6.35 & 2.67 & 0.48 & 3.20 & 14 \\
5 & 1 & $29 / 01 / 1948,07: 00$ & 6.32 & 2.61 & 0.51 & 3.21 & 10 \\
6 & 12 & $17 / 10 / 2012,05: 15$ & 6.32 & 2.66 & 0.31 & 3.35 & 10 \\
7 & 13 & $03 / 01 / 2014,06: 00$ & 6.32 & 2.77 & 0.18 & 3.37 & 37 \\
8 & 5 & $07 / 04 / 1985,18: 00$ & 6.32 & 2.61 & 0.54 & 3.16 & 9 \\
9 & 15 & $02 / 03 / 2014,05: 00$ & 6.31 & 2.76 & 0.27 & 3.27 & 9 \\
10 & 11 & $23 / 12 / 1995,05: 00$ & 6.29 & 2.70 & 0.18 & 3.41 & 9 \\
11 & 19 & $30 / 03 / 2006,05: 00$ & 6.27 & 2.84 & 0.25 & 3.18 & 7 \\
12 & 27 & $03 / 03 / 2014,06: 00$ & 6.27 & 2.74 & 0.25 & 3.27 & 5 \\
13 & 26 & $14 / 12 / 2012,04: 45$ & 6.26 & 2.65 & 0.32 & 3.29 & 5 \\
14 & 24 & $08 / 10 / 2006,17: 30$ & 6.26 & 2.82 & 0.07 & 3.38 & 5 \\
15 & 10 & $06 / 10 / 1979,17: 00$ & 6.26 & 2.77 & 0.27 & 3.22 & 9 \\
16 & 23 & $08 / 10 / 2002,18: 00$ & 6.26 & 2.76 & 0.15 & 3.35 & 5 \\
18 & 22 & $22 / 01 / 1996,05: 45$ & 6.25 & 2.73 & 0.10 & 3.41 & 5 \\
18 & 21 & $24 / 12 / 1995,06: 00$ & 6.25 & 2.78 & 0.11 & 3.35 & 5 \\
19 & 29 & $10 / 03 / 2001,05: 00$ & 6.24 & 2.70 & 0.30 & 3.24 & 5 \\
20 & 37 & $17 / 10 / 2012,17: 30$ & 6.24 & 2.63 & 0.26 & 3.35 & 5 \\
\end{tabular}

The months in which the high waters that were $\geq$ the 1 in 5 year and $\geq$ the 1 in 10-year return period are also shown in Fig. 4a. To date these have all occurred between October and April.

Based on these results, we divided the record into 99 annual intervals, each starting on the 1 July and ending on the 30 June the following year. The 1914-1915 window only starts on the 25 April 1915 and hence was excluded from this part of the analysis (of the 104 high waters in this interval, none register as $\geq$ the 1 in 1 -year return period). The $2013 / 2014$ window ends at midnight on the 30 June 2014, which was the last date for which we had data available at the time of analysis. Hence, we have 98 seasons in total spanning virtually 100 years. 
Table 3. Newlyn's high waters $\geq 1$ in 1 -year return period during winter 2013/2014, and also the notable 1995/1996 storm season.

\begin{tabular}{|c|c|c|c|c|c|c|c|}
\hline $\begin{array}{r}\text { Sea level } \\
\text { rank }\end{array}$ & $\begin{array}{r}\text { Return period } \\
\text { rank }\end{array}$ & $\begin{array}{l}\text { Date \& } \\
\text { time }\end{array}$ & $\begin{array}{l}\text { ObsSL } \\
(\mathrm{mCD})\end{array}$ & $\begin{array}{r}\text { Tide } \\
(\mathrm{mCD})\end{array}$ & $\begin{array}{r}\text { Skew surge } \\
(\mathrm{m})\end{array}$ & $\begin{array}{r}\text { MSL } \\
(\mathrm{mCD})\end{array}$ & $\begin{array}{r}\text { Return period } \\
\text { (years) }\end{array}$ \\
\hline \multicolumn{8}{|c|}{ The $2013 / 2014$ storm season } \\
\hline 7 & 13 & 03/01/2014, 06:00 & 6.32 & 2.77 & 0.18 & 3.37 & 9 \\
\hline 56 & 111 & 04/01/2014, 06:15 & 6.15 & 2.73 & 0.04 & 3.37 & 1 \\
\hline 39 & 74 & $01 / 02 / 2014,05: 30$ & 6.18 & 2.80 & 0.00 & 3.38 & 2 \\
\hline 1 & 3 & 03/02/2014, 07:00 & 6.44 & 2.61 & 0.45 & 3.37 & 34 \\
\hline 9 & 15 & 02/03/2014, 05:00 & 6.31 & 2.76 & 0.27 & 3.27 & 8 \\
\hline 12 & 27 & 03/03/2014, 06:00 & 6.27 & 2.55 & 0.30 & 3.27 & 1 \\
\hline \multicolumn{8}{|c|}{ The $1995 / 1996$ storm season } \\
\hline 97 & 126 & 24/11/1995, 05:30 & 6.10 & 2.68 & 0.09 & 3.33 & 1 \\
\hline 99 & 127 & $22 / 12 / 1995,04: 30$ & 6.10 & 2.55 & 0.14 & 3.41 & 1 \\
\hline 80 & 106 & $22 / 12 / 1995,16: 45$ & 6.12 & 2.47 & 0.24 & 3.41 & 1 \\
\hline 10 & 11 & 23/12/1995, 05:00 & 6.29 & 2.70 & 0.18 & 3.41 & 9 \\
\hline 18 & 21 & 24/12/1995, 06:00 & 6.25 & 2.73 & 0.10 & 3.41 & 5 \\
\hline 25 & 39 & $25 / 12 / 1995,06: 45$ & 6.20 & 2.65 & 0.15 & 3.41 & 4 \\
\hline 81 & 110 & 21/01/1996, 05:00 & 6.11 & 2.69 & 0.05 & 3.37 & 1 \\
\hline 18 & 22 & $22 / 01 / 1996,05: 45$ & 6.25 & 2.78 & 0.11 & 3.35 & 5 \\
\hline 44 & 58 & 23/01/1996, 06:15 & 6.17 & 2.73 & 0.09 & 3.34 & 2 \\
\hline 72 & 94 & 20/03/1996, 05:15 & 6.13 & 2.70 & 0.24 & 3.18 & 2 \\
\hline 59 & 75 & 21/03/1996, 05:45 & 6.14 & 2.68 & 0.28 & 3.19 & 2 \\
\hline
\end{tabular}

The number of high waters per season $\geq$ the 1 in 1 -year return period, $\geq$ the 1 in 5-year return period and $\geq$ the 1 in 10-year return period are shown in Fig. 4b. Interestingly, all $\geq 1$ in 1-year return-year high waters fall into just 62 of the 98 seasons. In fact, the top five seasons in which 1 in 1year high waters occur $(1995 / 1996,1984 / 1985,2013 / 2014$, 1997/1998, 1935/1936) account for 35 of the 147 high waters (i.e. $\sim 25 \%$ of the high waters fall into just $5 \%$ of the seasons); demonstrating that clustering is inherent in extreme sea levels. These five seasons are linked to larger return period levels: 10 occurrences of $\geq 1$ in 5 -year return period and three $\geq 1$ in 10-year return period. The seasons with the largest counts tend to have occurred in the 1920s, 1930s, 1940s and 1980s, 1990s, 2000s and 2010s (Fig. 4c). Relatively few extreme high waters occurred in the 1910s, 1950s and 1960s.

There are four particularly extreme high waters in terms of return period: 29 January 1948 (37 year); 7 April 1985 (27 year); 27 October 2004 (35 year); and 3 February 2014 (34 year). The 10 March 2008 is also a notable recent high water with a return period of 14 years. With the exception of the 3 February 2014 and 7 April 1985, these high waters did not occur during the years with the most number of high waters $\geq$ the 1 in 1-year return period.

The seasons with at least three occurrences of high waters that were $\geq$ the 1 in 1-year return period are listed in Table 4 . The 2013/2014 season is joint third for the largest number of $\geq 1$ in 1-year high water events in a season, and joint first for the largest number of $\geq 1$ in 5-year return-year events (Ta- ble 4). There were six high waters $\geq$ the 1 in 1 -year return period threshold during the season, and there were three occasions $\geq$ the 1 in 5 -year return period (see Table 3 ). The years $1995 / 1996$ had the largest number of $\geq 1$ in 1-year high waters in a season. During this period eleven high waters were $\geq$ the 1 in 1 -year return period threshold (see Table 3 ). Three of these high waters were $\geq$ the 1 in 5 -year return period. The $1984 / 1985$ and 1997/1998 seasons also rank highly for event frequency $\geq$ the 1 in 1-year return period, but the latter saw fewer occurrences of $\geq 1$ in 5-year and 1 in 10-year return period high waters.

The number of days between the first and last $\geq 1$ in 1-year high water is also listed in Table 4. The season of 1944/1945 is interesting with the widest time spacing between its interval of sea level extremes, with two events occurring 222 days apart (4 September 1944 and 14 April 1945). Contrastingly, $1992 / 1993$ had its $\geq 1$ in 1-year return period high waters clustered into three consecutive tidal cycles (29-30 August 1992). Similarly small "inter-event spacings" have occurred later in other storm seasons; for example, the events of April 1985, when from 6 to 7 April 1985, three $\geq 1$ in 1 -year high waters occurred, including a 1 in 27 and 1 in 16year event, which caused widespread flooding in Cornwall (Cornwall Council, 2011).

\section{Discussion and conclusions}

In this paper we have focused on an assessment of the high waters at Newlyn over the past 100 years that are $\geq$ the 1 

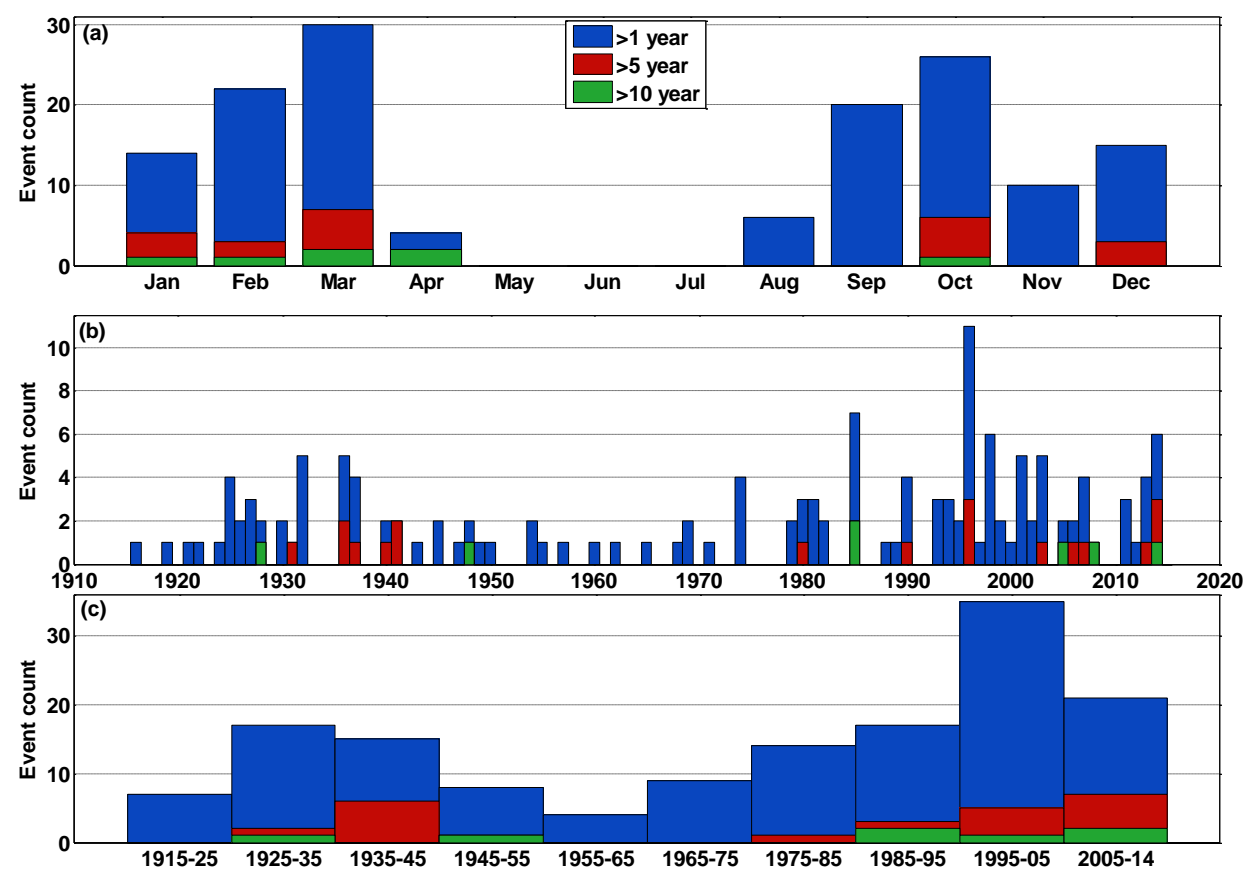

Figure 4. (a) Months in which extreme sea level events fall at Newlyn (for the entire 1915-2014 data set, for single tidal cycle events with return periods classified by the $1.81 \mathrm{~mm}_{\text {year }}{ }^{-1}$ SLR offset). (b) Counts of extreme sea level events (using the offset return periods) in July-July years; (c) counts of extreme sea level events grouped by decades.

in 1-year sea level return period. MSL has risen at Newlyn by around $18 \mathrm{~cm}$ since records began in 1915. In order to directly compare the return levels of high waters throughout the record, we needed to offset this by the observed rise in MSL. In this analysis we have offset using a simple linear trend of $1.81 \mathrm{~mm} \mathrm{yr}^{-1}$ over the duration of the record (which is the rate we estimate when fitting a trend to the annual MSL values at Newlyn, using linear regression). We found that the number and return period of offset high waters that are $\geq$ the 1 in 1-year return period is sensitive to the rate of MSL chosen. For example, if we offset the record by a rate of $3 \mathrm{~mm} \mathrm{yr}^{-1}$ (which is unrealistic for the whole record, but close to the global rate of MSL rise observed in the altimetry record post-1993; Church and White, 2006); this additional $1.2 \mathrm{~mm} \mathrm{yr}^{-1}$ offset across the record: (1) increases the count of the number of extreme event occurrences to 294; and (2) increases the return period of the 29 January 1948 high water from a 1 in 37-year return period to a $>1$ in 100year return period. Therefore, care should be taken when undertaking such analyses to ensure that the offset rate is determined in a rigorous manner. We have assumed that MSL rise has been linear, which is a reasonable assumption for the 20th century around the UK (Woodworth et al., 2009; Haigh et al., 2009; Wahl et al., 2013). However, more complex trend analysis will be needed as accelerations in MSL rise are becoming evident (Calafat and Chamners, 2013; Haigh et al., 2014; Ezer and Atkinson, 2014), and changes in tidal range should also be accounted for at some locations (Woodworth, 2010; Haigh et al., 2010b; Mawdsley et al., 2014).

We obtained 147 distinct high waters $\geq$ the 1 in 1-year return period, when offsetting the time series of high waters using the linear trend of $1.81 \mathrm{~mm} \mathrm{yr}^{-1}$ over the duration of the record. This large number of 1 in 1-year water levels, in this 100-year data set, appears contradictory to the notion of an "annual" sea level return period. However, return periods give a probability of an event occurring in any one year rather than an exact measure of how many will occur across a given time span. Discrepancies are furthered by inter-annual and multi-decadal fluctuations in MSL, differences in heights of high water from the (older) hourly data compared with the (newer post 1993) 15 minutely data, and missing data. However, this method is still useful for assessing extreme sea levels over time.

The overall aim of this paper is to assess how unusual the 2013/2014 winter period of coastal flooding has been in the UK, compared with the winters of the last century, in terms of "clustering" (i.e. whether or not the number of large events that occurred over a short time period was unusual). In undertaking this simple, but detailed analysis, it has emerged that extreme high waters "cluster" in different ways, and it is important to explore these before giving our conclusions. We have identified four main types of clusters in the record at Newlyn, which we can refer to as: (1) tidal clusters; (2) fortnightly clusters; (3) seasonal clusters; and (4) decadal clusters. By "tidal" cluster we mean high waters that have 
Table 4. Newlyn's storm seasons which have registered $\geq 3$ occurrences of sea level events exceeding the (offset) 1 in 1-year return period (ordered by this and then the exceedance of the 1 in 5-year return period). Also shown are the largest return periods and length of each "season" (as defined by events occurring of $\geq 1$ in 1 -year return period).

\begin{tabular}{|c|c|c|c|c|c|c|c|}
\hline Year & $\begin{array}{r}\text { Number of } \\
\geq 1 \text { in } 1 \text { year } \\
\text { events }\end{array}$ & $\begin{array}{r}\geq 1 \\
\text { in } 5 \text { year }\end{array}$ & $\begin{array}{r}\geq 1 \\
\text { in } 10 \text { year }\end{array}$ & $\begin{array}{l}\text { Max. return } \\
\text { period event }\end{array}$ & $\begin{array}{r}\text { MSL } \\
\text { average }\end{array}$ & $\begin{array}{l}\text { Average high } \\
\text { high water }\end{array}$ & $\begin{array}{l}\text { Season length } \\
\text { (days between first \& last } \\
\geq 1 \text { in } 1 \text {-year event) }\end{array}$ \\
\hline $1995 / 1996$ & 11 & 3 & 0 & 9 & 3.24 & 5.09 & 118 \\
\hline 1984/1985 & 7 & 2 & 2 & 27 & 3.21 & 4.97 & 193 \\
\hline $2013 / 2014$ & 6 & 3 & 1 & 34 & 3.27 & 5.12 & 59 \\
\hline 1997/1998 & 6 & 0 & 0 & 3 & 3.20 & 5.07 & 194 \\
\hline $1935 / 1936$ & 5 & 2 & 0 & 10 & 3.15 & 4.89 & 190 \\
\hline $2002 / 2003$ & 5 & 1 & 0 & 5 & 3.27 & 5.04 & 58 \\
\hline $1931 / 1932$ & 5 & 0 & 0 & 4 & 3.09 & 4.82 & 87 \\
\hline $2000 / 2001$ & 5 & 0 & 0 & 5 & 3.24 & 5.06 & 165 \\
\hline 1936/1937 & 4 & 1 & 0 & 7 & 3.11 & 4.88 & 192 \\
\hline $1989 / 1990$ & 4 & 1 & 0 & 5 & 3.21 & 4.96 & 91 \\
\hline $2006 / 2007$ & 4 & 1 & 0 & 5 & 3.25 & 5.00 & 164 \\
\hline $2012 / 2013$ & 4 & 1 & 0 & 9 & 3.26 & 5.09 & 58 \\
\hline $1924 / 1925$ & 4 & 0 & 0 & 1 & 3.07 & 4.85 & 89 \\
\hline 1973/1974 & 4 & 0 & 0 & 2 & 3.14 & 4.91 & 32 \\
\hline $1979 / 1980$ & 3 & 1 & 0 & 9 & 3.16 & 4.94 & 107 \\
\hline 1926/1927 & 3 & 0 & 0 & 2 & 3.06 & 4.86 & 163 \\
\hline $1980 / 1981$ & 3 & 0 & 0 & 2 & 3.14 & 4.91 & 163 \\
\hline $1992 / 1993$ & 3 & 0 & 0 & 3 & 3.15 & 4.96 & 1 \\
\hline $1993 / 1994$ & 3 & 0 & 0 & 3 & 3.17 & 5.01 & 164 \\
\hline $2010 / 2011$ & 3 & 0 & 0 & 2 & 3.22 & 5.02 & 29 \\
\hline
\end{tabular}

exceeded our threshold on consecutive tidal cycles or consecutive days, and are most likely associated with a single storm. We observe examples where two or even three consecutive high waters are $\geq$ the 1 in 1-year return period, and other occasions where the first and third high water exceed the threshold. The latter tends to happen when diurnal tidal equality (due to the declination of the Moon; Pugh, 2004) is strongest, resulting in one high tide a day being lower than the other. The "fortnightly clusters" we refer to are extreme high waters that occur within a few days of each other, but are most likely not associated with the same storm. These tend to occur during the 7 days of a spring-neap tidal cycle, when tides are relatively large (i.e. during spring tide). If a storm occurs during neap tides, the total water level is not likely to be high enough to lead to flooding. By "seasonal clusters", we refer to particular seasons (between August and April), like the 2013/14 winter, when there were an unusual number of extreme high waters in a season. This might arise (as discussed below in more detail) due to wider meteorological forcing (e.g. locking of the jet stream) during that season, or that longer-term tidal modulations, in particular the 4.4-year cycle of lunar perigee, are around their maximum during that period (Haigh et al., 2011). "Decadal" clusters are decades characterised by an unusual number of extreme high waters over multiple years, such as the 1930s and 1990s (Fig. 4c). Again these might be linked to regional changes in climate, such as the North Atlantic oscillation and the Atlantic Multi- decadal oscillation, or peaks in the 18.6-year lunar nodal tidal cycle.

We now briefly examine possible mechanisms that might cause specific seasons or decades to have a larger number of extreme high waters. We do this visually, in Fig. 5, by comparing time series of annual high water counts with different components of sea level and the North Atlantic oscillation (NAO). The NAO has previously been shown to influence both MSL and extreme sea levels (e.g. Wakelin et al., 2003; Woolf et al., 2003; Betts et al., 2004; Yan et al., 2004; Tsimplis et al., 2005; Woodworth et al., 2007; Araújo and Pugh, 2008; Haigh et al., 2010a). We also correlate the seasonal counts of high waters $\geq$ the 1 in 1-year return period, and the seasonal average height of these high waters, against these various time series; correlation coefficients are listed in Table $5 \mathrm{a}$ and $5 \mathrm{~b}$, respectively.

Time-series of annual mean high waters ( $\geq$ the 1 in 1-year return period) and MSL for each July-July storm season are shown in Fig. 5a and b respectively, along with the observed linear trend. The 4.4-year cycle of lunar perigee and the 18.6year lunar nodal tidal cycle are shown in Fig. 5c (with the darker thicker line showing the net effect of these superimposed upon one another). When combined they alter tidal levels at Newlyn by up to $20 \mathrm{~cm}$. Figure $5 \mathrm{~d}$ shows seasonal counts of the skew surges associated with the high waters that reached or exceeded different return period thresholds. The winter NAO index is shown in Fig. 5e. The length of 

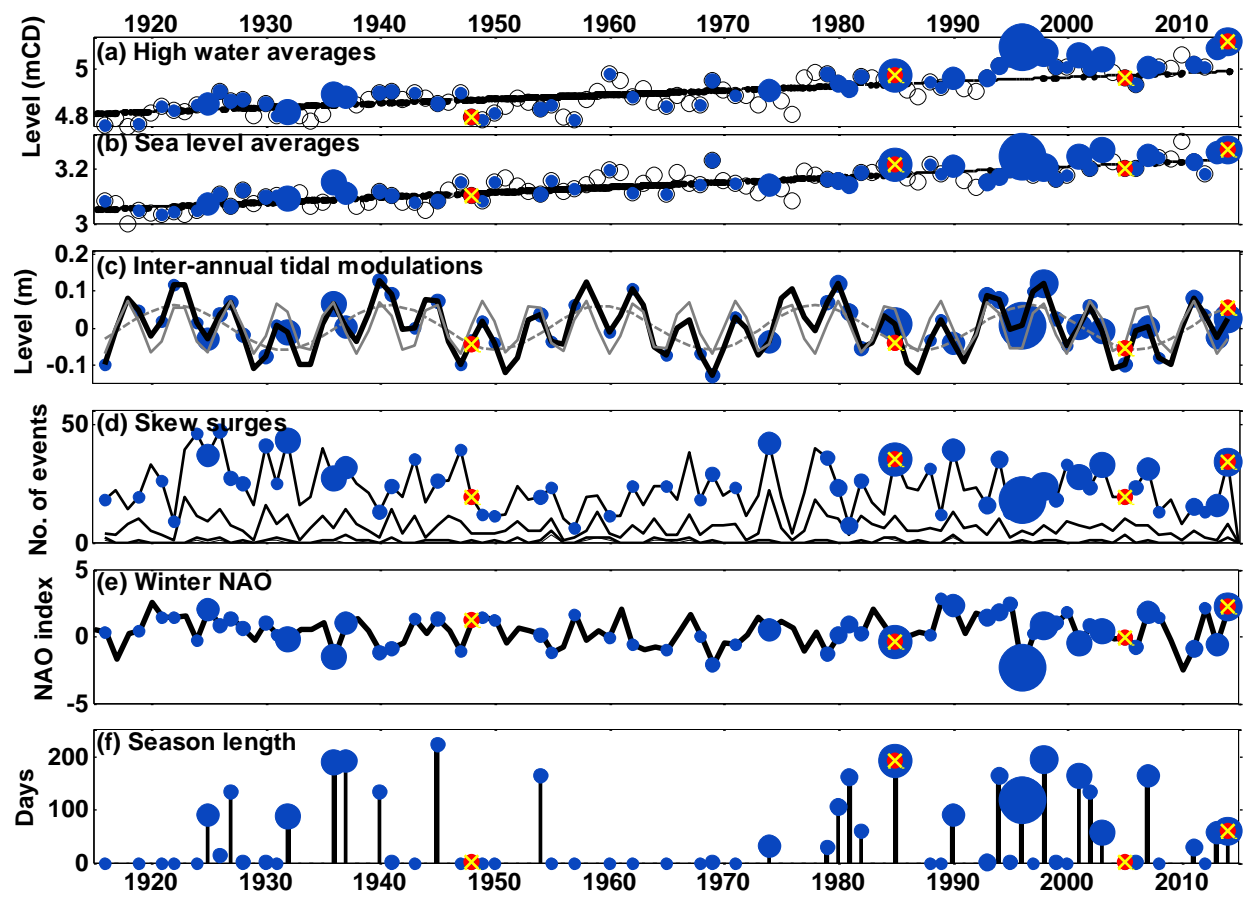

Figure 5. Blue dots (superimposed on each chart) represent the count of $\geq 1$ in 1-year high waters in each July-July annual period (i.e. larger dots indicate larger clusters). The red-yellow markers highlight the four "big" one-off return period events (in 1948, 1985, 2004 and 2014). (a) Average height of high waters each season; (b) mean sea level in each season, with the linear trend; (c) Inter-annual tidal modulations: $4.4 \mathrm{yr}$ (solid grey), $18.6 \mathrm{yr}$ (dashed grey) and combined (solid black line); (d) seasonal count of skew surge events exceeding the thresholds averagely associated with $\geq 1$ in $1,5,10$ and 20-year high water $(0.24,0.34,0.50$ and $0.55 \mathrm{~m}$, respectively); (e) the winter North Atlantic oscillation (NAO) index, station-based, computed from the difference between normalised sea level pressure measurements from Gibraltar and Reykjavik, southwest Iceland; from the Climate Research Unit (CRU), University of East Anglia (http://www.cru.uea.ac.uk/cru/data/ nao.htm); (f) span of time (days) between the first and last $\geq 1$ in 1-year events of each July-July season,.

the season (i.e. the number of days between the first and last high water $\geq$ the 1 in 1-year threshold in each season) is plotted in Fig. 5f. Superimposed on the time series are blue dots (Fig. 5), the size of which is proportional to the number of events $\geq$ the 1 in 1-year high waters; allowing us to infer (visually) why certain seasons had a greater number of extreme high waters.

The large number of high waters in several seasons in the mid-1990's, and in the past few seasons, coincides with MSL being higher than average, both on a year-to-year basis and in terms of the century scale increase (Fig. 5b). During both periods the 18.6-year lunar nodal tidal cycle has been at or near to its peak (Fig. 5c). In addition, the number of larger skew surges was reasonably large during this period (Fig. 5d). This indicates that whilst a mechanism influencing extreme high waters at Newlyn, the number of larger skew surge events in each season is not intrinsically linked to larger counts of $\geq 1$ in 1-year return period high waters (although exceptional skew surges have caused some of the bigger individual events, e.g. 1985 and 2004). This is primarily due to the large tidal range and relatively small surge component. The number of larger positive skew surges is variable; ranging from only four skew surges $\geq 0.24 \mathrm{~m}$ in 1975/1976 to 54 skew surges $\geq 0.24 \mathrm{~m}$ in $1923 / 1924$ (with a standard deviation of 10). The seasons of 1995/1996 and 2013/2014 both had 30 skew surges $\geq 0.24 \mathrm{~m}$, of which (as already shown in Table 4) respectively led to 11 and 7 high waters of levels $\geq$ the 1 in 1-year return period. The large number of extreme high waters in the 1920s and 1930s coincide with a larger number of large skew surge events (i.e. those typically associated with extreme high waters), but do not align with the peaks in the nodal cycle, which occurred around 1921 and 1940 . The number of high waters $\geq$ the 1 in 1 -year return period was relatively low in the 1950s and 1960s. On average the number of larger skew surge events was smaller over this period (Fig. 5d). Three of the four most extreme high waters on record ( $>25$-year plus return period), shown by the red and yellow markers in Fig. 5, occurred at lower times in the lunar nodal cycle (Fig. 5c).

There is no obvious or straightforward relationship evident in Fig. 5 between high water count and the winter NAO. However, the low number of extreme high water counts (and low counts of skew surges; Fig. 5d.) in the 1910s, 1920s, 1950s and 1960s, appear to coincide with periods when the average variability in the (winter) NAO was smaller. On a year-to-year basis, abrupt winter NAO transitions are asso- 
Table 5a. Correlation of the seasonal counts of high waters $\geq 1$ in 1-year return period and various seasonal time series, with lower and upper $95 \%$ confidence intervals for each coefficient.

\begin{tabular}{lrrr}
\hline Variable & $\begin{array}{r}\text { Correlation } \\
\text { coefficient }\end{array}$ & $\begin{array}{r}\text { Lower 95\% } \\
\text { interval }\end{array}$ & $\begin{array}{r}\text { Upper 95\% } \\
\text { interval }\end{array}$ \\
\hline Average sea level & 0.37 & 0.19 & 0.53 \\
Average high water & 0.49 & 0.31 & 0.62 \\
Average sea level (de-trended for 1.81 $\mathrm{mm} \mathrm{yr}^{-1}$ ) & 0.28 & 0.09 & 0.45 \\
Average high water (de-trended for 1.81 $\mathrm{mm} \mathrm{yr}^{-1}$ ) & 0.53 & 0.37 & 0.66 \\
NAO (winter index) & -0.07 & -0.27 & 0.13 \\
NAO (index change from prev. season) & -0.16 & -0.35 & 0.04 \\
LNC 18.6 yr & 0.14 & -0.06 & 0.33 \\
LP 4.4 yr & 0.16 & -0.04 & 0.34 \\
LNC \& LP combined & 0.10 & -0.10 & 0.29 \\
Skew surges (assoc. with 1 in 1 yr HWs) & 0.29 & 0.10 & 0.46 \\
\hline
\end{tabular}

Table 5b. Correlation of the seasonal average height of high waters and various seasonal time series, with lower and upper $95 \%$ confidence intervals.

\begin{tabular}{lrrr}
\hline Variable & $\begin{array}{r}\text { Correlation } \\
\text { coefficient }\end{array}$ & $\begin{array}{r}\text { Lower 95\% } \\
\text { interval }\end{array}$ & $\begin{array}{r}\text { Upper 95\% } \\
\text { interval }\end{array}$ \\
\hline Skew surge & 0.43 & 0.06 & 0.43 \\
NAO (winter index) & 0.09 & -0.29 & 0.11 \\
NAO (index change from prev. season) & -0.16 & -0.34 & 0.04 \\
LNC 18.6 yr & 0.47 & 0.31 & 0.61 \\
LP 4.4 yr & 0.25 & 0.06 & 0.43 \\
LNC \& LP combined & 0.42 & 0.24 & 0.57 \\
\hline
\end{tabular}

ciated with distinct cluster years (Fig. 5e). For example, the 1995/1996 season experienced a very strong negative winter NAO phase (Halpert and Bell, 1997). When the NAO is negative, the tracks of storms tend to be further south, which would increase the number of storm surge events at Newlyn (Haigh et al., 2010). There was a positive winter NAO for the 2013/2014 season, although the exceptional number of storms during this period has been more strongly linked to the unusually strong westerly phase of the stratospheric Quasi-biennial oscillation (QBO), which in turn has driven a very deep polar vortex and strong polar night jet (MetOffice, 2014). As observed by Betts et al. (2004), severe surge events in this region are a function of several interacting factors: individual storm duration; average deepening rate; the pressure value (of the outermost closed isobar encircling the storm centre); and the minimum longitudinal position of this isobar.

Correlation coefficients between time series of seasonal high water counts and the various time series mentioned above are typically less than 0.5 (Table 5a). There is a positive and statistically significant correlation (at the $95 \%$ confidence interval) between the high water count and (i) the de-trended annual MSL component (correlation coefficient 0.28 ); and (ii) the skew surge count (correlation coefficient 0.29). Correlations with the inter-annual tidal modulations are positive, but not statistically significant at the $95 \%$ con- fidence interval. Correlation with the winter NAO is negative (correlation coefficient -0.07 ), but not statistically significant at the $95 \%$ confidence interval. Correlation with the winter NAO difference (i.e. the change from previous season) is stronger (correlation coefficient -0.16 ). These results highlight the complexity of understanding clustering in sea level time series because of the combined influence of multiple components. Unsurprisingly, correlation between the seasonal average height of all of the semi-diurnal high waters, and the sea level components are stronger (Fig. 5a). In the future we plan to undertake a much more detailed assessment of the possible mechanisms influencing seasonal counts of extreme high waters, including examining the influence of other climate indices (such as the Atlantic multi-decadal oscillation).

Our analysis has shown that clustering of extreme sea levels is inherent in the tide gauge records. Clustering is an important subject because short intervals between extreme high waters will mean that manmade and/or natural coastal and flood defences (e.g. sea walls, beaches) and receptors (e.g. communities, businesses) are not likely to have enough time to recover, and hence will be more vulnerable. The length and effectiveness of such a "storm memory" period is however location and system specific. Defining clusters in the manner shown here is a starting point for analysis of the effects of memory in the system. However, further work could in- 


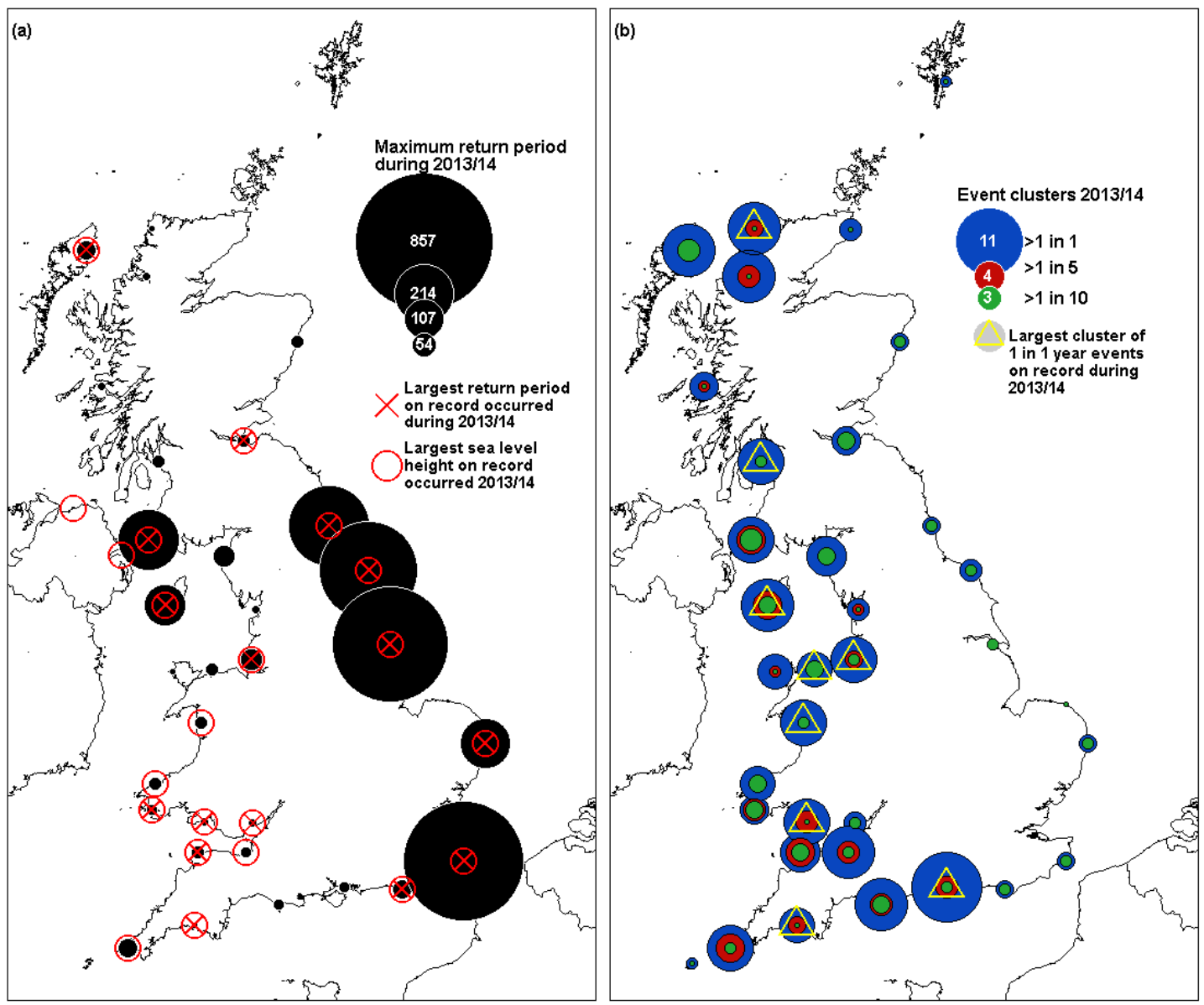

Figure 6. The methods shown for Newlyn are extended to the UK's Class A tide gauge sites (for which both return periods and 2013/2014 sea level time series are available); (a) the largest return periods during the July-July 2013/2014 year (note that the return period data set does not cover Bangor, Portrush and Jersey); (b) clustering of events above the 1 in 1-year return period threshold. For reference to the locations and data spans at each location, see Fig. 1b.

corporate additional event parameters that define the significance of each risk event such as duration of each extreme sea level, and other processes such as surface gravity waves, pluvial and fluvial inputs, which are critical to damage and flood risk at the coast. From a practical perspective, future research into susceptibility (e.g. of defences or communities) to repeated shocks in a given time period makes the notion of clustering more clearly defined.

The number of high waters exceeding given thresholds will continue to increase (as has been observed for the last century; Fig. 2a) as MSL continues to rise, and will accelerate with accelerations in MSL (Ezer and Atkinson, 2014). Future changes with storm activity are more complex and could increase or decrease clustering, depending on how the magnitude, frequency and tracks of storms vary. An analysis of cyclone frequency and intensity indicated that the IrelandUK 2013/14 winter experienced the most severe storminess for at least 143 years (Matthews et al., 2014). Looking to the future, climate models (applied to mid-range 21st century climate projections) indicate a slight December-February increase in the number and intensity of cyclones associated with strong wind speeds found over the UK and central Europe (Zappa et al., 2013). As shown here, the severe storminess of October 2013 to February 2014, with exceptional tides (which continued into March) allowed for a large number of extreme high water events at UK tide gauge sites over a relatively short period. Clearly, a detailed analysis of how climate change might alter sea level clustering in the future is needed.

Returning to the original aim of the paper, we conclude that the 2013/2014 winter period was distinctive at Newlyn. The latest season generated the highest sea level at Newlyn since records began in April 1915. This occurred on 3 February 2014 and was $0.02 \mathrm{~m}$ higher than the previous largest on 27 October 2004. After accounting for MSL rise, this high water has the third highest return period (34 year) after the high water on 29 January 1948 (37-year return period) and 27 October 2004 (35 year). The 2013/2014 season had the 
joint largest number of high waters at Newlyn that were $\geq$ the 1 in 5-year return period and the third largest number of high waters that were $\geq$ the 1 in 1 -year return period.

In this paper, we have focused on analysing the Newlyn tide gauge record, because it is the longest sea level time series for the UK. The latest winter was unusual at Newlyn, but it is likely to be even more distinctive at other UK locations where flooding was more pronounced and wide-spread. We are in the process of analysing the shorter records (Fig. 1b) at the other UK tide gauge sites, using the methods developed here. An initial assessment, the results of which are summarised in Fig. 6, reveals that the 2013/2014 season produced: the biggest return period sea level at 16 active sites across the UK (Fig. 6a, red crosses); the biggest sea level height at 22 sites (Fig. 6a, red circles); and the biggest $\geq 1$ in 1-year event cluster at 9 sites (Fig. 6b, size of circles indicates number of extreme high waters), and notable clusters of larger events ( $\geq 1$ in 5 and $\geq 1$ in 10-year high waters indicated respectively by red and green circles). In a followup study, an additional aim is to look at the spatial extent (or "footprint") of the coastline impacted by different events, complimented by an analysis of storm tracks.

Acknowledgements. We thank the British Oceanographic Data Centre for providing the sea level data and the Environment Agency (EA) for providing the return period statistics. All the authors were funded through the Engineering and Physical Science Research Council Flood Memory Project (grant number EP/K013513/1).

Edited by: E. J. M. Delhez

\section{References}

Araújo, I. B. and Pugh, D. T.: Sea levels at Newlyn 1915-2005: analysis of trends for future flooding risks, J. Coastal Res., 24, 203-212, 2008.

Batstone, C., Lawless, M., Tawn, J., Horsburgh, K., Blackman, D., McMillan, A., Worth, D., Laeger, S., and Hunt, T.: A UK bestpractice approach for extreme sea-level analysis along complex topographic coastlines, Ocean Eng., 71, 28-39, 2013.

Baxter, P. J.: The east coast Big Flood, 31 January-1 February 1953: a summary of the human disaster, Philos. T. R. Soc. A, 363, 1293-1312, 2005.

BBC: 10 key moments of the UK winter storms, 17 February 2014, BBC News, available at: http://www.bbc.co.uk/news/ uk-26170904 (last access: 7 May 2014), 2014a.

BBC: Channel Islands flooded after "highest tide of the year", 3 March 2014, BBC News, available at: http://www.bbc.co.uk/ news/world-europe-jersey-26390204 (last access: 7 May 2014), 2014b.

BBC: Coastal communities in Devon and Cornwall flooded, 3 February 2014, last updated at 20:58, available at: http:// www.bbc.co.uk/news/uk-england-26012890 (last access: March 2014), 2014c.
Betts, N. L., Orford, J. D., White, D., and Graham, C. J.: Storminess and surges in the South-Western Approaches of the eastern North Atlantic: the synoptic climatology of recent extreme coastal storms, Mar. Geol., 210, 227-246, 2004.

Bütow, H.: Die große Flut in Hamburg. Eine Chronik der Katastrophe vom Februar 1962, Freie und Hansestadt Hamburg, Schulbehörde, 1963.

Calafat, F. M. and Chambers, D. P.: Quantifying recent acceleration in sea level unrelated to internal climate variability, Geophys. Res. Lett., 40, 3661-3666, 2013.

Cornwall Council: Preliminary Flood Risk Assessment. ANNEX 5 - Chronology of Major Flood Events in Cornwall, June 2011, Cornwall Council, 2011.

Church, J. A. and White, N. J.: A 20th century acceleration in global sea-level rise, Geophys. Res. Lett., 33, L01602, doi:10.1029/2005GL024826, 2006.

Church, J. A., Clark, P. U., Cazenave, A., Gregory, J. M., Jevrejeva, S., Levermann, A., Merrifield, M. A., Milne, G. A., Nerem, R. S., Nunn, P. D., Payne, A. J., Pfeffer, W. T., Stammer, D., and Unnikrishnan, A. S.: Sea Level Change. Climate Change 2013: The Physical Science Basis. Contribution of Working Group I to the Fifth Assessment Report of the Intergovernmental Panel on Climate Change, edited by: Stocker, T. F., Qin, D., Plattner, G.-K., Tignor, M., Allen, S. K., Boschung, J., Nauels, A., Xia, Y., Bex, V., and Midgley, P. M., Cambridge University Press, Cambridge, UK and New York, NY, USA, 2013.

De Kraker, A. M. J.: Flood events in the southwestern Netherlands and coastal Belgium, 1400-1953, Hydrolog. Sci. J., 51, 913-929, 2006.

de Vries, H., Breton, M., de Mulder, T., Krestenitis, Y., Ozer, J., Proctor, R., Ruddick, K., Salomon, J. C., and Voorrips, A.: A comparison of 2-D storm surge models applied to three shallow European seas, Environ. Softw., 10, 23-42, 1995.

Doodson, A. T.: Tides and storm surges in a long uniform gulf, Proc. R. Soc. Lon. Ser.-A, 237, 325-343, 1956.

Easterling, G.: Mount's Bay on 27 October 2004 - Storm Surge and Flooding, Graham Easterling's Weather Pages: Major Local Weather Events, available at: http://www.turnstone-cottage. co.uk/PzStorm.PDF (last access: October 2013), 2004.

Environment Agency: Properties flooded since the start of December 2013, Environment Agency map figure, reference number 100026380, 2014.

Ezer, T. and Atkinson, L. P.: Accelerated flooding along the U.S. East Coast: On the impact of sea-level rise, tides, storms, the Gulf Stream, and the North Atlantic Oscillations, Earth's Future, 2, 362-382, 2014.

Gerritsen, H.: What happened in 1953? The Big Flood in the Netherlands in retrospect, Philos. T. R. Soc. A, 363, 1271-1291, 2005.

Gill, A. E.: Atmosphere-Ocean Dynamics, Academic Press, 1982.

Gönnert, G., Murty, T., and Siefert, W.: Global Storm Surges: Theory Observation and Application - vol. 63, 2001.

Haigh, I. D., Nicholls, R. J., and Wells, N. C.: Mean sea-level trends around the English Channel over the 20th century and their wider context, Cont. Shelf. Res., 29, 2083-2098, 2009.

Haigh, I., Nicholls, R., and Wells, N.: Assessing changes in extreme sea levels: application to the English Channel, 1900-2006, Cont Shelf. Res., 30, 1042-1055, 2010a. 
Haigh, I. D., Nicholls, R., and Wells, N.: A comparison of the main methods for estimating probabilities of extreme still water levels, Coast. Eng., 57, 838-849, 2010b.

Haigh, I. D., Eliot, M., and Pattiaratchi, C.: Global influences of the $18.61 \mathrm{yr}$ nodal cycle and $8.85 \mathrm{yr}$ cycle of lunar perigee on high tidal levels, J. Geophys. Res., 116, C06025, doi:10.1029/2010JC006645, 2011.

Haigh, I. D., Wahl, T., Rohling, E. J., Price, R. M., Pattiaratchi, C. B., Calafat, F. M., and Dangendorf, S.: Timescales for detecting a significant acceleration in sea level rise, Nature Communications, 5, 3635, doi:10.1038/ncomms4635, 2014.

Hallegatte, S., Green, C., Nicholls, R. J., and Corfee-Morlot, J.: Future flood losses in major coastal cities, Nature Clim. Change, 3, 802-806, 2013.

Halpert, M. S. and Bell, G. D.: Climate assessment for 1996, B. Am. Meteorol. Soc., 78, 1038-1038, 1997.

Hanson, S., Nicholls, R., Ranger, N., Hallegatte, S., Corfee-Morlot, J., Herweijer, C., and Chateau, J.: A global ranking of port cities with high exposure to climate extremes, Clim. Change, 104, 89$111,2011$.

Horsburgh, K. and Horritt, M.: The Bristol Channel floods of 1607 - reconstruction and analysis, Weather, 61, 272-277, 2006.

Horsburgh, K. J. and Wilson, C.: Tide-surge interaction and its role in the distribution of surge residuals in the North Sea, J. Geophys. Res., 112, 1-13, 2007.

Jonkman, S. N. and Vrijling, J. K.: Loss of life due to floods, J. Flood Risk Manage., 1, 43-56, 2008.

Jonkman, S. N., Maaskant, B., Boyd, E., and Levitan, M. L.: Loss of life caused by the flooding of New Orleans after hurricane Katrina: analysis of the relationship between flood characteristics and mortality, Risk Anal., 29, 676-698, 2009.

Kolen, B., Slomp, R., van Balen, W., Terpstra, T., Bottema, M., and Nieuwenhuis, S.: Learning from French Experiences with Storm Xynthia - Damages After a Flood, HKV LIJN IN WATER and Rijkswaterstaat, Waterdienst, 2010.

Lamb, H.: Historic storms of the North Sea, British Isles and Northwest Europe, Cambridge, Cambridge University Press, 1991.

LeComte, D.: International weather highlights 2013: super typhoon Haiyan, super heat in Australia and China, a long winter in Europe, Weatherwise, 67, 20-27, 2014.

Le Pard, G.: The great storm of 1824, Proceedings of Dorset Natural History and Archaeological Society, 121, 23-36, 1999.

Lewis, J.: Vulnerability to a natural hazard: geomorphic, technological and social change at Chiswell, Dorset, Natural Hazard Research, Working Paper no. 37, available at: http://www.colorado. edu/UCB/Research/IBS/hazards/publications/wp/wp37.pdf, 1979.

Lumbroso, D. M. and Vinet, F.: A comparison of the causes, effects and aftermaths of the coastal flooding of England in 1953 and France in 2010, Nat. Hazards Earth Syst. Sci., 11, 2321-2333, doi:10.5194/nhess-11-2321-2011, 2011.

Mailier, P. J., Stephenson, D. B., Ferro, C. A. T., and Hodges, K. I.: Serial clustering of extratropical cyclones, Mon. Weather Rev., 134, 2224-2240, 2006.

Matthews, T., Murphy, C., Wilby, R. L. and Harrigan, S.: Stormiest winter on record for Ireland and UK, Nat. Clim. Change, 4, 738$740,2014$.
Mawdsley, R. J., Haigh, I. D., and Wells, N. C.: Global changes in mean tidal high water, low water and range, J. Coast. Res., 343348, 2014.

McMillan, A., Batstone, C., Worth, D., Tawn, J. A., Horsburgh, K., and Lawless, M.: Coastal flood boundary conditions for UK mainland and islands. Project: SC060064/TR2: Design sea levels, Environment Agency, Bristol, UK, 2011.

McRobie, A., Spencer, T., and Gerritsen, H.: The Big Flood: North Sea storm surge, Philos. T. R. Soc. A, 363, 1263-1270, 2005.

MetOffice: The recent storms and floods in the UK - February 2014. Met Office and the Centre for Ecology and Hydrology, Natural Environmental Research Council, 2014.

Neria, Y. and Shultz, J. M.: Mental health effects of Hurricane Sandy: characteristics, potential aftermath, and response, JAMAJ. Am. Med. Assoc., 308, 2571-2572, 2012.

Pawlowicz, R., Beardsley, B., and Lentz, S.: Classical tidal harmonic analysis including error estimates in MATLAB using T_TIDE, Comput. Geosci., 28, 929-937, 2002.

Plüß, A., Rudolph, E., and Schrödter, D.: Characteristics of storm surges in German estuaries, Clim. Res., 18, 71-76, 2001.

Prandle, D. and Wolf, J.: The interaction of surge and tide in the North Sea and River Thames, Geophys. J. Roy. Astr. S., 55, 203216, 1978.

Proudman, J.: The propagation of tide and surge in an estuary, Proc. R. Soc. Lon. Ser.-A, 231, 8-24, 1955.

Proudman, J.: Oscillations of tide and surge in an estuary of finite length, J. Fluid Mech., 2, 371-382, 1957.

Pugh, D. T.: Tides, Surges and Mean Sea-Level. A Handbook for Engineers and Scientists, Wiley, Chichester, 2004.

Quinn, N., Lewis, M., Wadey, M., and Haigh, I.: Assessing the temporal variability in extreme storm?tide time series for coastal flood risk assessment, J. Geophys. Re.-Oceans, 119, 4983-4998, doi:10.1002/2014JC010197, 2014.

RMS: December 1703 windstorm, 300 yr retrospective, Risk Management Solutions Report, 2003.

RMS: Hurricane Katrina: Profile of a Super Cat, Lessons and Implications for Catastrophe. Risk Management Solutions, available at: http://www.rms.com (last access: 14 June 2011), 2005.

RMS: 1607 Bristol Channel Floods: 400 yr retrospective. Risk Management Solutions Report, available at: http://www.rms.com/ resources/publications/natural-catastrophes (last access: 27 January 2012), 2007.

Rossiter, J. R.: Interaction between tide and surge in the Thames, Geophys. J. Roy. Astr. S., 6, 29-53, 1961.

SCOPAC: Storm damage sustained to coastal assets across the SCOPAC region 17 January - end of February 2014. Report by the "Standing Conference on Problems Associated with the Coastline", available at: http://www.scopac.org.uk/downloads. html (last access: April 2014), 2014.

Scotto, M. G., Alonso, A. M., and Barbosa, S. M.: Clustering time series of sea levels: Extreme value approach, J. Waterw. Port Coast. Ocean. Eng., 136, 215-225, 2009.

Steers, J. A.: The east coast floods, 31 January-1 February 1953, Geogr. J., 119, 280-295, 1953.

Tsimplis, M., Woolf, D., Osborn, T., Wakelin, S., Wolf, J., Flather, R., Shaw, A., Woodworth, P., Challenor, P., and Blackman, D.: Towards a vulnerability assessment of the UK and northern European coasts: the role of regional climate variability, Philos. T. R. Soc. A, 363, 1329-1358, 2005. 
Villarini, G., Smith, J. A., Vitolo, R., and Stephenson, D. B.: On the temporal clustering of US floods and its relationship to climate teleconnection patterns, Int. J. Climatol., 33, 629-640, doi:10.1002/joc.3458, 2013.

Vitolo, R., Stephenson, D. B., Cook, I. M., and Mitchell-Wallace, K.: Serial clustering of intense European storms, Meteorol. Z., 18, 411-424, 2009.

Wahl, T., Jensen, J., Frank, T., and Haigh, I.: Improved estimates of mean sea level changes in the German Bight over the last $166 \mathrm{yr}$, Ocean Dynam., 61, 701-715, 2011.

Wahl, T., Haigh, I. D., Dangendorf, S., and Jensen, J.: Inter-annual and long-term mean sea level changes along the North Sea coastline, J. Coastal Res., Special Issue, 65, 1987-1992, 2013.

Wakelin, S., Woodworth, P., Flather, R., and Williams, J.: Sea-level dependence on the NAO over the NW European continental shelf, Geophys. Res. Lett., 30, 1403, doi:10.1029/2003GL017041, 2003.

West, I. M.: Hurst spit, barrier beach of the West Solent, Hampshire: geology of the Wessex Coast, available at: http://www. southampton.ac.uk/ imw/chestorm.htm (last access: 1 August 2014), 2010.
Woodworth, P., Flather, R., Williams, J., Wakelin, S., and Jevrejeva, S.: The dependence of UK extreme sea levels and storm surges on the North Atlantic Oscillation, Cont. Shelf. Res., 27, 935-946, 2007.

Woodworth, P., White, N. J., Jevrejeva, S., Holgate, S., Church, J., and Gehrels, W.: Evidence for the accelerations of sea level on multi-decade and century timescales, Int. J. Climatol., 29, 777789, 2009.

Woodworth, P.: A survey of recent changes in the main components of the ocean tide, Cont. Shelf. Res., 30, 1680-1691, 2010.

Woolf, D. K., Shaw, A. G., and Tsimplis, M. N.: The influence of the North Atlantic Oscillation on sea-level variability in the North Atlantic region, The Global Atmosphere and Ocean System, 9, 145-167, 2003.

Yan, Z., Tsimplis, M. N., and Woolf, D.: Analysis of the relationship between the North Atlantic oscillation and sea-level changes in northwest Europe, Int. J. Climatol., 24, 743-758, 2004.

Zappa, G., Shaffrey, L. C., Hodges, K. I., Sansom, P. G., and Stephenson, D. B.: A multimodel assessment of future projections of North Atlantic and European Extratropical Cyclones in the CMIP5 Climate Models, J. Climate, 26, 5846-5862, 2013. 